\title{
PATTERNS OF THE AQUATIC MACROPHYTE COVER IN CACHOEIRA DOURADA RESERVOIR (GO-MG)
}

\author{
BINI, L. M., ${ }^{1}$ OLIVEIRA, L. G., ${ }^{1}$ SOUZA, D. C., ${ }^{2}$ CARVALHO, P. ${ }^{1}$ and PINTO, M. P. ${ }^{1}$ \\ ${ }^{1}$ Departamento de Biologia Geral, Instituto de Ciências Biológicas, Universidade Federal de Goiás, \\ C.P. 131, CEP 74001-970, Goiânia, GO, Brazil \\ ${ }^{2}$ Programa de Pós-graduação em Ecologia de Ambientes Aquáticos Continentais, Universidade Estadual de \\ Maringá, CEP 87020-900, Maringá, PR, Brazil \\ Correspondence to: Luis M. Bini, Departamento de Biologia Geral, Instituto de Ciências Biológicas, Universidade \\ Federal de Goiás, C.P. 131, CEP 74001-970, Goiânia, GO, Brazil, e-mail: bini@icb1.ufg.br \\ Received April 14, 2003 - Accepted October 10, 2003 - Distributed February 28, 2005
}

(With 2 figures)

\begin{abstract}
The relationship between the aquatic macrophyte cover in upper segments of tributaries and this cover in these tributaries but near the reservoir's main body was tested. Sixteen taxa belonging to 12 families of aquatic macrophytes were recorded in Cachoeira Dourada reservoir. The most frequent species were Eichhornia azurea (frequency of occurrence $=92 \% ; n=37$ sites) and E. crassipes (44\%). Upper segments of the tributaries were the main areas colonized by these aquatic macrophytes. The positive relationship between the aquatic macrophyte cover between the upper and lower segments of tributaries indicates the importance of dispersion in the colonization of the arms and the reservoir's main body.
\end{abstract}

Key words: aquatic macrophytes, cover, reservoirs.

\section{RESUMO}

\section{Padrões de cobertura de macrófitas aquáticas no reservatório de Cachoeira Dourada (GO-MG)}

Neste trabalho, foi realizado um levantamento da riqueza e da composição de espécies de macrófitas aquáticas no reservatório de Cachoeira Dourada (GO-MG). Os dados obtidos foram utilizados para testar se há relação positiva e significativa entre a cobertura de macrófitas aquáticas nos segmentos superiores dos tributários (próximo às nascentes) e a cobertura de macrófitas aquáticas nos mesmos tributários, próxima ao corpo central. Foram identificados 16 taxa, pertencentes a 12 famílias. Eichhornia azurea, a espécie mais freqüente no reservatório, ocorreu em $92 \%$ dos locais visitados, enquanto E. crassipes ocorreu em $44 \%$ dos locais. Os trechos superiores dos tributários foram as principais regiões colonizadas por macrófitas aquáticas. A relação positiva entre a cobertura de macrófitas aquáticas nos segmentos superiores e inferiores dos tributários indica a importância da dispersão para a colonização dos braços e corpo central do reservatório.

Palavras-chave: macrófitas aquáticas, cobertura, reservatórios.

\section{INTRODUCTION}

Aquatic macrophytes play a very important role in aquatic ecosystems (Carpenter \& Lodge, 1986; Esteves \& Camargo, 1986). However, in disturbed bodies of water some species, due to their excessive growth, may interfere with human use of freshwater, as well as recreation, fishing, water supply, and electrical generation, besides creating conditions conducive to the development of disease vectors (Pieterse \& Murphy, 1993).

Abundant aquatic macrophyte growth is a common feature of reservoir systems in sub-tropical and tropical regions, especially because reservoir 
construction causes many changes in lotic ecosystems, mainly reductions in water velocity, water transparency, sediment stability, and water-level control, as well as increased shoreline development and construction in previously sheltered areas. In addition, these environments are frequently subject to eutrophication, which may enhance the growth of free-floating nuisance species (Thomaz \& Bini, 1998). Thus, the problems caused by the growth of these plants are really symptoms and not the first causes of existing impacts (Cook, 1993).

Besides the most frequent impacts caused by floating species such as Eichhornia crassipes (Mart.) Solms, Pistia stratiotes L., and Salvinia molesta D. L. Mitchell, and the submerged macrophytes have required attention due their high nuisance potential. Rapid inventories of aquatic macrophytes in Brazilian reservoirs are important in that they register potential nuisance species at local scales, increase information about distribution at a broader scale, and can be used in testing specific ecological hypotheses. As an example of the latter use, Thomaz \& Bini (1998) pointed out that the aquatic macrophyte cover in reservoir arms, near a reservoir's main body, may be positively correlated with the same type of cover in the tributaries (in the upper segments).

The main aim of this study was to test the expected positive relationship between the aquatic macrophyte cover in the reservoir arms near the main body, and this cover in the upper segments of the tributaries or in the arms. To check this hypothesis, spatial data on aquatic macrophytes cover were obtained at Cachoeira Dourada reservoir.

\section{METHODS}

The Cachoeira Dourada reservoir (mean area $=74 \mathrm{~km}^{2}$ ) is an old impoundment existing since 1958 behind the Cachoeira Dourada dam on the Paranaíba

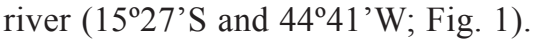

A survey of the macrophyte cover was undertaken in a total of 37 sites, distributed in the main reservoir body (17 sites), in the upper segments of the tributaries (10 sites), as well as in the lower ones near the reservoir main body (10 sites).

The aquatic macrophytes, whether freefloating, emergent, and rooted with floating leaves, were collected manually, while the submerged species were sampled with a grapnel. Species were identified to the lowest taxonomic level possible, according to Hoehne (1979), Tryon \& Tryon (1982), Cook \& Urmi-König (1984), Lowden (1986), Cook (1990), Lorenzi (1991), and Velásquez (1994).

Each plant species was ranked from 0 to 2 , according to the following criteria: species absence $=$ 0 ; presence of the species $=1$; species forming large homogeneous stands $=2$. Although simple, these standards were used to minimize uncertainties inherent in the use of more cover classes and a detailed cover scale, as a consequence of which two observers would be unlikely to agree (Barbour et al., 1987)

To test the main hypothesis of this study, covers were summed irrespective of species so as to provide a general measure of the macrophyte cover (MC) in each site in the tributaries. Afterwards, the Spearman rank correlation was used to test the relationship between $\mathrm{MC}$ values obtained for sites located in the upper segments of the tributaries $\left(\mathrm{MC}_{\mathrm{U}}\right)$ and those obtained for sites located in their lower reaches $\left(\mathrm{MC}_{\mathrm{L}}\right)$.

\section{RESULTS AND DISCUSSION}

Sixteen taxa were recorded in Cachoeira Dourada reservoir, making species richness in Cachoeira Dourada reservoir lower than those of other Brazilian reservoirs (Pedralli et al., 1993; Pedralli \& Meyer, 1996; Thomaz et al., 1999). At Itaipu binational reservoir, for example, 62 taxa were registered (Thomaz et al., 1999). Probably, the relatively limited area of Cachoeira Dourada reservoir and, consequently, its meager habitat heterogeneity, could explain this lower richness. However, it is important to emphasize differences in the sampling effort and more data is necessary to better estimate species richness in the Cachoeira reservoir.

According to Table 1, aquatic macrophyte species composition in Cachoeira Dourada reservoir could be considered a subset of the regional "pool" of species found in other Brazilian environments (Pott et al., 1989, 1992; Pedralli \& Gonçalves, 1997; Thomaz et al., 1999).

The pattern of the relative species cover observed in Cachoeira Dourada reservoir is also characteristic of other biological assemblages. In other words, few species are widely distributed in the reservoir, whereas most are rare. The species with the larger cover area and larger frequency of occurrence was Pontederiaceae. For example, 
Eichhornia azurea is the most frequent species (frequency of occurrence $=92 \%$ ) and $E$. crassipes occurred in $44 \%$ of the surveyed sites (Fig. 2a). Both species could be considered potential nuisances in the Cachoeira Dourada reservoir. According to Fernández et al. (1993), Eichhornia azurea is often considered a nuisance species in many Brazilian reservoirs, while $E$. crassipes is considered the main aquatic weed in South and Central America and in other regions of the world (Gopal, 1993).
Some other species, such as Salvinia auriculata e Egeria densa, with low cover and occurrence, deserve attention due to the problems they cause in many other reservoirs (see Pieterse \& Murphy, 1993). In other clear water reservoirs, $E$. densa is considered the main nuisance species (e.g., Jupiá and Paulo Afonso). Thus, considering the high water transparency at Cachoeira Dourada reservoir (mean Secchi disk $=1.7 \mathrm{~m} ; \mathrm{SD}=0.46$ $\mathrm{m} ; n=37)$, this species requires particular attention.

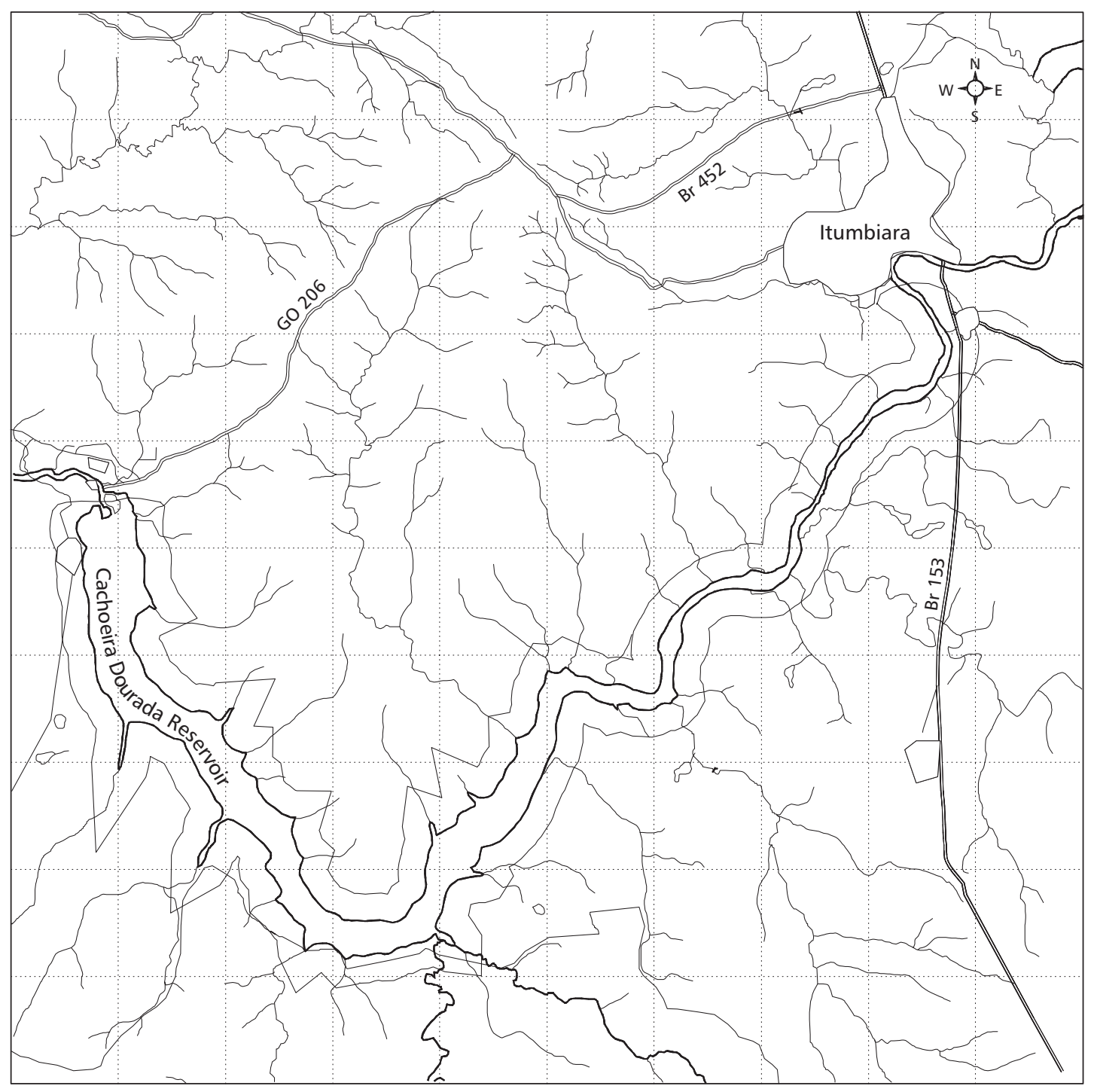

Fig. 1 - Map of Cachoeira Dourada reservoir (GO-MG). 

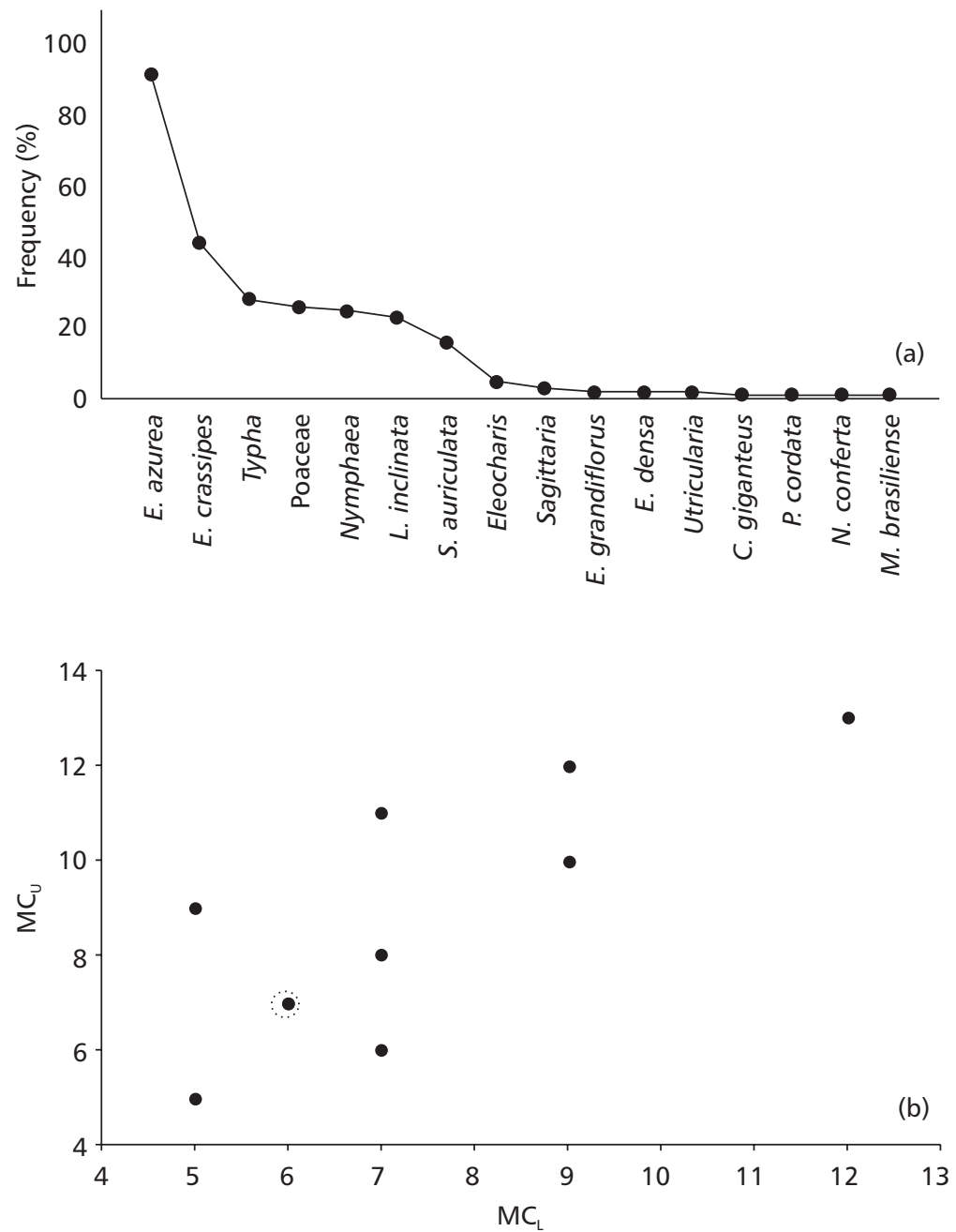

Fig. 2 - (a) Frequency of occurrence of the taxa registered in the Cachoeira Dourada reservoir (number of sampling sites =37). (b) Relationship between aquatic macrophytes cover in the upper segments $\left(\mathrm{MC}_{\mathrm{U}}\right)$ near the headwaters and in the lower segments $\left(\mathrm{MC}_{\mathrm{U}}\right)$ near the reservoir main body of Cachoeira Dourada reservoir $(n=10)$. The dot inside the circle indicates two observations with the same values.

Patterns of colonization by aquatic macrophytes could be considered predictable. Regions exposed to wind and wave action are rarely colonized by freefloating or emergent aquatic macrophytes (Thomaz \& Bini, 1998). Underwater light incidence and sediment declivity are also important predictors of submerged species occurrence (Duarte \& Kalf, 1986, 1990; Duarte et al., 1986; Thomaz et al., 1998). In Cachoeira Dourada reservoir, aquatic macrophyte growth (mainly by free-floating and emergent plants) was higher in the upper segments of the tributaries, when compared to that in the lower segments. This is corroborated by the paired signal test $(Z=2 ; \mathrm{p}=0.045 ; n=10)$. Upper segments were sheltered and had lower Secchi disk values (mean difference between upper and lower segments $=-31 \mathrm{~cm} ; t$ test $=3.5 ; n=10 ; \mathrm{p}=0.006$ ) when compared with those of the segments located near the main body of the reservoir. 
TABLE 1

Families, scientific names, and ecological groups for taxa collected at

Cachoeira Dourada reservoir in May 1999.

\begin{tabular}{|c|c|c|}
\hline Family & Taxon & Ecological group \\
\hline Typhaceae & Typha sp. & Emergent \\
\hline Salviniaceae & Salvinia auriculata Aublet & Free-floating \\
\hline Lentibulariaceae & Utricularia sp. & Free submerged \\
\hline Nymphaeaceae & Nymphaea sp. & Rooted with floating leaves \\
\hline Najadaceae & Najas conferta (A. BR.) Brasun & Submerged \\
\hline Hydrocharitaceae & Egeria densa Planchon & Submerged \\
\hline Haloragaceae & Myriophyllum brasiliense Cambess. & Emergent \\
\hline \multirow[t]{2}{*}{ Alismataceae } & $\begin{array}{c}\text { Echinodorus cf. grandiflorus (Cham. and } \\
\text { Schlecht.) M. Micheli }\end{array}$ & Emergent \\
\hline & Sagittaria sp. & Emergent \\
\hline Onagraceae & Ludwigia inclinata (L. f.) Gomez & Submerged \\
\hline \multirow[t]{3}{*}{ Pontederiaceae } & Pontederia cordata L. & Emergent \\
\hline & Eichhornia crassipes (Mart.) Solms. & Free-floating \\
\hline & Eichhornia azurea (Swartz) Kunth & Emergent \\
\hline \multirow[t]{2}{*}{ Cyperaceae } & Cyperus giganteus Vahl & Emergent \\
\hline & Eleocharis sp. & Emergent \\
\hline Poaceae & $\begin{array}{l}\text { Not identified due to absence of } \\
\text { reproductive structures }\end{array}$ & Emergent \\
\hline
\end{tabular}

A significant relationship between $\mathrm{MC}_{\mathrm{U}}$ and $\mathrm{MC}_{\mathrm{L}}$ was detected (Spearman $r=0.73 ; \mathrm{p}=0.017$; Fig. 2b). Thus, aquatic macrophyte covers in the upper tributary segments can be used to predict the cover of aquatic macrophytes in the tributaries near the reservoir's main body. This result supports the hypothesis of Thomaz \& Bini (1998), which holds that the tributaries act as a major source of viable propagules, the dispersion of which in the direction of the main body is important in maximizing the colonization of different regions in the reservoirs.

The results obtained in this study indicate that control programs and/or the management of aquatic macrophytes at local scales (generally in the reservoir main body) will rarely be successful due to continuous colonization by propagules originating in upper tributary segments, where aquatic vegetation is uncontrolled. Thus, despite evident difficulties, aquatic vegetation management should be undertaken at the regional scale.
Acknowledgements - We thank Dr. Odete Santos Vieira for identifying the Ludwigia inclinata. L. M. Bini and L. G. Oliveira are receiving financial support from the Conselho Nacional de Desenvolvimento Científico e Tecnológico (CNPq), the Coordenação para Aperfeiçoamento do Ensino Superior (CAPES), and the Pró-Reitoria de Pesquisa e Pós-Graduação (PRPPG) and FUNAPE of the Universidade Federal de Goiás.

\section{REFERENCES}

BARBOUR, M. G., BURK, J. H. \& PITTS, W. D., 1987, Terrestrial plant ecology. The Benjamin/Cummings Publishing Company, Inc., California, 634p.

CARPENTER, S. R. \& LODGE, D. M., 1986, Effects of submersed macrophytes on ecosystem processes. Aquat. Bot., 26: 341-370.

COOK, C. D. K., 1990, Aquatic plant book. SPB Academic, The Hague, The Netherlands, 228p.

COOK, C. D. K., 1993, Origin, autoecology, and spread of some of the world's most troublesome aquatic weeds. In: A. H. Pieterse \& J. K. Murphy (eds.), Aquatic weeds: the ecology and management of nuisance aquatic vegetation. Oxford University Press, Oxford. 
COOK, C. D. K. \& URMI-KÖNIG, K., 1984, A revision of the genus Egeria (Hydrocharitaceae). Aquat. Bot., 19: 73-96.

DUARTE, C. M. \& KALFF, J., 1986, Littoral slope as a predictor of the maximun biomass of submerged macrophyte communities. Limnol. Oceanogr., 31: 1072-1080.

DUARTE, C. M. \& KALFF, J., 1990, Patterns in the submerged macrophyte biomass of lakes and the importance of the scale of analysis in the interpretation. Can. J. Fish. Aquat. Sci., 47: $357-363$.

DUARTE, C. M., KALFF, J. \& PETERS, R. H., 1986, Patterns in biomass cover of aquatic macrophytes in lakes. Can. J. Fish. Aquat. Sci., 43: 1900-1908.

ESTEVES, F. A. \& CAMARGO, A. F. M., 1986, Sobre o papel das macrófitas aquáticas na estocagem e ciclagem de nutrientes. Acta Limnol. Brasil., 1: 273-298.

FERNÁNDEZ, O. A., SUTTON, D. L., LALLANA, V. H., SABBATINI, M. R. \& IRIGOYEN, J., 1993, Aquatic weed problems and management in South and Central America. In: A. H. Pieterse \& K. J. Murphy (eds.), Aquatic weeds: the ecology and management of nuisance aquatic vegetation. Oxford University Press, Oxford.

GOPAL, B., 1993, Aquatic weed problems and management in Asia. In: A. H. Pieterse \& K. J. Murphy (eds.), Aquatic weeds: the ecology and management of nuisance aquatic vegetation. Oxford University Press, Oxford.

HOEHNE, F. C., 1979, Plantas aquáticas. Instituto de Botânica Série D, São Paulo, 168p.

LORENZI, H., 1991, Plantas daninhas do Brasil: terrestres, aquáticas, parasitas, medicinais e tóxicas. Editora Plantarum, Nova Odessa (SP), 608p.

LOWDEN, R. M., 1986, Taxonomy of the genus Najas L. (Najadaceae) in the neotropics. Aquat. Bot., 24: 147-184.

PEDRALLI, G., MEYER, S. T., TEIXEIRA, M. C. \& STEHMANN, J. R., 1993, Levantamento de macrófitos aquáticos e da mata ciliar do reservatório de Volta Grande, Minas Gerais, Brasil. Iheringia, 43: 29-40.
PEDRALLI, G. \& MEYER, S. T., 1996, Levantamento da vegetação aquática ("macrófitas") e das florestas de galeria na área da Usina Hidrelétrica de Nova Ponte, Minas Gerais. Bios, 4(4): 49-60.

PEDRALLI, G. \& GONÇALVES, A. P. S., 1997, Levantamento florístico e aspectos da sucessão em duas lagoas da região cárstica de Minas Gerais, Brasil. Daphne, 7(3): 17-25.

PIETERSE, A. H. \& MURPHY, K. J., 1993, Aquatic weeds: the ecology and management of nuisance aquatic vegetation. Oxford University Press, Oxford, 593p.

POTT, V. J., BUENO, N. C., PEREIRA, R. A. C., SALIS, S. M. de \& VIEIRA, N. L., 1989, Distribuição de macrófitas aquáticas numa lagoa na fazenda Nhumirim, Necolândia, Pantanal, MS. Acta Bot. Bras., 3: 153-167.

POTT, V. J., BUENO, N. C. \& SILVA, M. P., 1992, Levantamento florístico e fitossociológico de macrófitas aquáticas em lagoas da Fazenda Leque, Pantanal, MS. $8^{\circ}$ Congresso da Sociedade de Botânica de São Paulo (SBSP), pp. 91-99.

THOMAZ, S. M. \& BINI, L. M., 1998, Ecologia e manejo de macrófitas aquáticas em reservatórios. Acta Limnol. Brasil., 10: 103-116.

THOMAZ, S. M., BINI, L. M. \& SOUZA, D. C., 1998, Biomass and maximum colonization depth of Egeria najas Planchon (Hydrocharitaceae) at Itaipu reservoir, Brazil. pp. 223-226. In: Proceedings of $10^{\text {th }}$ Ewrs Symposium on Aquatic Weeds, Lisbon. Lisboa, 1998.

THOMAZ, S. M., BINI, L. M., SOUZA, M. C., KITA, K. K. \& CAMARGO, A. F. M., 1999, Aquatic macrophytes of Itaipu reservoir, Brazil: Survey of species and ecological considerations. Braz. Arch. Biol. Tech., 42: 15-22.

TRYON, R. M. \& TRYON, A. F., 1982, Ferns and allied plants. with special reference to tropical America. Springer-Verlag, New York, 857p.

VELÁSQUEZ, J., 1994, Plantas acuáticas vasculares de Venezuela. Universidad Central de Venezuela, Consejo de Desarrollo Científico y Humanístico, Caracas, 992p. 
This article has received corrections in agreement with the ERRATUM published in Volume 65 Number 2. 